\title{
Potential impulse buying on product Honda Motor in West Java
}

\author{
Mohamad Ropik*, Maya Ariyanti** \\ * Marketing Management Science, Telkom University Bandung, Indonesia \\ ** School of Economics and Business, Telkom University Bandung, Indonesia \\ DOI: 10.29322/IJSRP.11.01.2021.p10986 \\ http://dx.doi.org/10.29322/IJSRP.11.01.2021.p10986
}

\begin{abstract}
The rapid era of globalization 4.0 has an impact on people's increasingly consumptive lifestyle. This phenomenon also affects to producers in marketing their products, thus creating a competitive climate in an increasingly competitive industry. Honda Motor in West Java is the top of the automotive industry market in terms of motorcycles, which has dominated market share for the past five years. Event marketing is known as a promotional activity that dominates Honda Motor's marketing strategy in West Java. However, the objective of event activities is not specifically directed at generating hard sales, while sales promotion programs are implemented intensively in each of these event activities.

This study analyzes sales promotion and event image on event marketing activities carried out by Honda Motor in West Java, as well as the potential impulse buying of consumers on motorcycle products that are influenced by these two variables. The research method is quantitative with a survey approach to the population of valid product buyers registered on event period February - March 2020 in the cities of Bekasi and Bandung. The sample size was determined by non-probability sampling using a purposive sampling technique of 63 samples. SEM-PLS is used as an analysis technique through structural equation modeling with the second order confirmatory factor analysis procedures.

The results showed that the respondents' responses to the impulse buying variable were in the good category (71.4\%). The analysis of the direct effect from sales promotion and event image to impulse buying showed an influence of 0.132 with sales promotion having a positive and significant impact on impulse buying, while event image did not positive and significant effect on consumer impulse buying. This implication concludes that there is a potential impulse buying behavior among Honda motorcycle consumers in West Java which can be explained by the influenced of sales promotion program at the event being held, so the implementation of objectives in event marketing activities can be determined explicitly by Honda Motor Company to generate direct sales (hard sales) through sales promotion programs that can motivate impulsive buying behavior.
\end{abstract}

Index Terms- Impulse buying, sales promotion, event image, event marketing, structural equation modelling.

\section{INTRODUCTION}

$\mathrm{T}$ he era of globalization 4.0 has rapidly entered to Indonesia, this is marked by the entry of increasingly sophisticated technology that emphasizes digital economy, artificial intelligence, big data, robotic, and so on. This phenomenon is known as disruptive innovation. Globalization is identical with a free market economy causes a fusion and shift of cultures, one of them is a consumptive culture (Gischa, 2020). The consumptive culture formed by the impact of the development of the globalization era is thought to have given forth the phenomenon of consumer behavior in impulsive purchases. Impulse buying is a common behavior in today's era. Consumption culture allows people to give up on various tempting offers and ultimately buy something without considering the consequences of the purchases they have made (Zimmerman, 2020). Era of globalization 4.0 also affects producers in marketing their products in such a way that consumers are lulled into a consumptive culture by various strategies in persuading consumers to make continuous purchases because the trend is always up to date. The government has launched a road map for making Indonesia 4.0 as a clear strategy and direction in developing the national industries in this era of globalization 4.0. In the roadmap of making Indonesia 4.0, the automotive industry is one of the five manufacturing sectors chosen to be a pioneer in the implementation of the industrial revolution 4.0, in addition to four other sectors, that are the food and beverage industry, the textile and clothing industry, the chemical industry and the electronics industry (kemenperin.go.id, 2020).

Every year the various of motorcycle models are launched, this makes consumers have many references in choosing to buy a motorbike according to what consumers like with various purchase motives. The motorcycle industry of Indonesia began in 1971 which was pioneered by PT. Astra Honda Motor (AHM), at that time still had the name PT. Federal Motor. PT. Daya Adicipta Motora (DAM) is the main distributor of Honda motorcycles and spare parts in West Java which contributes to PT. Astra Honda Motor. Based 
on data obtained from the ministry of industry, data processed by the association of Indonesian motorcycle industry (AISI), the realization of motorcycle sales in Indonesia during 2019 experienced a growth of $1.6 \%$ compared to the previous year. Total motorcycle production in 2019 reached 7,297,648 units, which is domestic distribution contributed 6,487,460 units, up from 6,383,108 units previously (aisi.or.id/statistic, 2020). From these data, PT. Astra Honda Motor (AHM) as the agent holder of the Honda motorbike brand in Indonesia is still strong at the peak of motorcycle sales in the 2019 period with a market share of $75.7 \%$ or $4,910,688$ units with a flat 3\% growth (Kuswaraharja, 2020). Regional market analysis shows that the total percentage of new motorcycle absorption by West Java reaches approximately 17\%, followed by East Java at $15.7 \%$ and DKI Jakarta at around $12 \%$ (ARF, 2019). In 2019 Honda Motor still remains as the leader of the motorcycle market in the West Java with an increased in market share by $1.1 \%$ to $83.1 \%$ from $82 \%$ in the previous year (Sales Marketing \& Logistics PT.DAM, 2020), this percentage can be projected that PT. DAM sold 895,927 units of motorcycle, with the largest contribution still projected to be automatic type 822,149 units, sport type 46,534 units and the remaining cub type contributed 27,243 units.

The achievement of sales figures for Honda Motor West Java cannot be separated from the marketing strategy adopted by PT. AHM and PT.DAM through several promotional programs which are run every year. In 2019, it was noted that the promotional programs run by PT. DAM, 57\% is dominated by event marketing and sponsorship activities. This figure has increased the promotional quota on the event side by $5 \%$ compared to the previous year which was $52 \%$. Based on the positive achievement of sales, it can be assumed that there are no problems in the marketing strategy implemented. However, in the implementation of event marketing activities in the field, sales promotion programs as part of the sales department program, with event activities that are part of the promotion department programs, there are often gaps related to the objectives set in various lines of event marketing activities carried out. Each department has its own key performance indicators, and in the end, event activities are often directed either directly or indirectly to the dominant objective towards achieving brand image. This means that the implementation of event marketing activities that contain sales promotion programs and activities that lead to the event image is not focused specifically on generating hard sales. The potential for impulse buying behavior is not considered and this is further strengthened by the understanding that motorcycle products that have a relatively high price value are considered reasonable if they generate soft sales.

\section{LITERATURE REVIEW}

\section{A. Impulse buying}

Marketers must have a thorough understanding of how consumers behave to be able to offer clear and precise value to each targeted consumer. Consumer behavior is a series of value-seeking activities carried out by a person to meet their needs. This means that the needs become the basic motivation for consumers to think, feel, and behave in order to create sufficient value. When value creation is fulfilled, the next process is the creation of desire (Babin and Harris, 2016). Consumer behavior can be described as a study that involves an individual or group process of selecting, buying, using or disposing of products, services, ideas, or experiences to satisfy their needs and wants (Solomon et al., 2016). In line with this opinion, Kotler and Keller (2016) state that consumer behavior is the study of how individuals, groups and organizations choose, buy, use, and dispose of goods, services, ideas, or experiences to satisfy their needs and wants. Impulse buying occurs when consumers experience a strong and persistent desire to buy something suddenly and immediately (Rook, 1987). Meanwhile other literature confirms the strength of impulse buying encourage that occur in the individuals, impulse buying is different from unplanned purchases, when someone suddenly feels the boost that cannot resist, that is impulse buying (Solomon et al., 2016). Impulse buying can be explained from an experiential perspective, this purchase is often motivated by feelings, where consumers buy products spontaneously and with little attention to the consequences (Babin and Harris, 2016). The factors that can trigger impulsive purchases and have relevance to the object of research on motorcycle products can be identified into ten measurement dimensions, including: urge to purchase, positive emotions, negative emotions, shopping enjoyment, availability of money, availability of time, impulse tendency, promotion scheme, point of sales terminal/ATM facility and product category (Beatty and Ferrel, 1998; Pradhan, 2018).

\section{B. Sales promotion}

Sales promotion includes techniques that companies can use as part of their product marketing activities in an effort to achieve various goals, such as encouraging repeat purchases, building long-term customer loyalty, encouraging consumers to visit certain sales outlets, building retail stock levels, expanding or increasing product distribution (Jobber and Lancaster, 2015). Sales promotion is a major element in a marketing campaign, consisting of a set of incentive tools, mostly short-term, designed to stimulate the faster or greater purchase of a particular product or service by consumers (Kotler and Keller, 2016; Kotler and Armstrong, 2018). Sales promotion can be linked with the goal of shaping consumer behavior, where the incentives given to customers can encourage changes in their behavior according to marketers' goals (Wirtz and Lovelock, 2018). Sales promotion as the tools to motivate consumers which is intended as an incentive or incentive to make a purchase immediately. The tools that are the measurement dimensions can be identified as stated by Kotler and Keller (2016), including: samples, coupons, cash refund offers/rebates, price packs/cents-off deals, 
premium/gift, frequency programs, prizes (contest, sweepstakes and games), patronage awards, free trials, product warranties, tie-in promotions, cross promotion, point-of-purchase, price-off, allowance, free goods, trade shows and conventions, sales contest, specialty advertising. When associated with the goal of forming impulse buying behavior, sales promotion as incentive tools can be used as a significant measurement dimension consist of: loyalty program, price discount, free samples, buy one-get one free (Weerathunga and Pathmini, 2016). Mamuaya (2018) confirmed the dimensions of sales promotion with the sample, coupons, and price packing. In addition to the literature review, factor selection was carried out based on the results of interviews with experts related to the company being the object of research to produce indicators that were relevant and in accordance with the formulation of this study. The results of this study focus on eight dimensions of sales promotion, including: price discounts, free trial/riding tests, prizes (contests, sweepstakes, games), price packs, POP displays, loyalty programs, product warranties and cross promotions.

Sales promotion has a significant impact on impulse buying behavior that occurs in consumers (Weerathunga and Pathmini, 2016; Mamuaya, 2018). Sales promotion and hedonic shopping simultaneously have a positive impact on impulse buying (Amanah and Pelawi, 2015). Sales promotion is a strong predictor of hedonic and utilitarian and also the results show that hedonic is the strongest predictor of impulse buying (Metilda and Karthika, 2015). Therefore, the author put forward the first research hypothesis related to the relationship between sales promotion and impulse buying, that:

\section{H1. Sales Promotion has a significant positive effect on Impulse Buying.}

\section{Event image}

Apart from needing a tool to convey the message of the product value proposition in marketing, there is also an effective way to communicate the brand message. One effective way is with event marketing activities. It is a form of brand promotion that binds the brand with public activities that have high interest value (Shimp and Andrews, 2013). In order to connect the concept of event marketing used with empirical facts on the results of its impact on targeted consumer behavior, the variables to be measured are determined based on how the consumer's memory and knowledge can be composed through the formation of the perception of the event being held. The cumulative interpretation of the meanings or associations associated with events by consumers is called event images (Gwinner in Deng et al., 2015). Event image from a psychosociology perspective is a cognitive construction that connects a rational and effective representation of an event by a person or group (Ferrand and Pages in Deng et al., 2015). Event image is a function that combines elements of event types, event characteristics and individual factors. And an important note is the element of individual factors because it relates to perceptions that are influenced by individual assessment factors based on information obtained from previous experiences (Gwinner, 1997 in Hallmann et al., 2011).

Event image is generally considered to have the same theoretical foundation as brand image, which is based on the framework of Kotler and Keller's model of brand equity. Brand image and event image are formed and composed in the mechanism of human memory and knowledge. An important characteristic of an event image that is similar to a brand image is its dynamic nature. Event image does not remain in the human mind because it is influenced by various factors, as well as brand image. 17 items of event image measurement indicators were identified as the results of the extraction from five dimensions which has demonstrated the reliability and validation as a strong measurement scale. The dimensions referred to include: benefits, facilities, services, themes and event content (Deng et al., 2015).

Brand image has a positive effect on impulse buying, while the use of promotional strategies can generally affect consumer evaluation of brand image, but the effect depends on the type of promotional tools used and the product category being promoted, promotions that involve non-monetary leads to a higher increase in brand image. (Husnul et al., 2017). To build a strong brand image, it is necessary to take branding steps that will provide brand strength and be a powerful way to strengthen the competitive advantage of products and services. (Kotler and Keller, 2016). Branding has a significant impact and predicts a good proportion of variants in impulse buying behavior (Husnain and Akhtar, 2016). Based on the explanation, the author put forward the second research hypothesis related to the relationship between event image and impulse buying, that:

\section{H2. Event Image has a significant positive effect on Impulse Buying.}

Promotion affects the consumer evaluation of brand image, but the effect depends on the type of promotion tool and product category. Frequent use of promotions that involve monetary (price) will decrease the assessment of the brand image, while promotions that involve non-monetary leads to an increase in a higher brand image. These results are moderated by the product category variable (Montaner and Pina, 2018). The utilitarian value of sales promotion has the maximum impact on brand loyalty, whereas the hedonic value of sales promotion has the maximum impact on the brand association. The hedonic value of sales promotion can be used to make consumers related to brand image, while the utilitarian value of sales promotion can be used to increase repurchase (Sinha and Verma, 2018). This underlies the author in proposing the third hypothesis regarding the relationship between sales promotion and event image, that: 
H3. Sales Promotion has a significant positive effect on Event Image.

Promotion and brand image affect impulse buying, and the one that most influences impulse buying is promotion (Husnul et al., 2017). Sales promotion can be used to make consumers related to brand image (Sinha and Verma, 2018). Regarding the relationship above, the author put forward the fourth hypothesis, that:

H4. Sales promotion has a significant positive effect on Impulse Buying with Event Image as an intervening variable.

\section{RESEARCH METHODS}

The type of research applied is descriptive causal. The type of descriptive research is designed to describe the phenomenon of consumer impulse buying behavior on motorcycle products, while a causal approach is used to analyze the relationship of how the effect of sales promotion and event image on impulse buying consumers of Honda motorbikes in West Java (Sekaran and Bougie, 2016; Indrawati, 2105). The method used in this research is quantitative with a survey strategy that allows collecting data that occurs in the past or present about beliefs, opinions, characteristics, behaviors, variable relationships and/or testing several hypotheses about sociological and psychological variables on a sample from a particular population, with data collection techniques through interviews or questionnaires, research results tend to be generalized (Sugiyono, 2019). Quantitative methods in business research usually measure consumer behavior, knowledge, opinions or attitudes (Cooper and Schindler, 2014).

Visitors who bought Honda motorcycle during the event were the target respondents in this study, respondent data was obtained from the registration process at the sales booth of Regional Public Launching Honda BeAT event for the period 8-9 February 2020 at Summarecon Mall in Bekasi and Honda Premium Matic Day event for the period 7- 8 March 2020 at Paskal 23 Mall in Bandung. On the event, there were 63 registered visitors as consumers who were valid purchased a product of Honda motorcycle. The determination of total samples was based on the sampling method using a non-probability sampling technique, namely purposive sampling. It was the deliberate selection of certain samples by researchers to produce logical samples that represent or can provide information to answer research problems (Indrawati, 2015). To measure respondents' attitudes, opinions and perceptions, a Likert scale was used with a statement on a five-point scale, starting from the lowest point 1 (one) is strongly disagree and the highest point 5 (five) is strongly agree (Sekaran and Bougie, 2016).

Data analysis techniques in quantitative research are using statistics (Sugiyono, 2019). The statistics used in this study are descriptive statistics, because the authors only describe the sample data, and do not make conclusions that apply to the population where the sample is drawn. Descriptive analysis is based on obtaining a total score for each variable dimension compared to the ideal score obtained from the answers of all respondents who are assumed to answer strongly agree. Then the results are interpreted based on the score criteria based on the range value obtained from the largest cumulative value minus the smallest cumulative value and divided by five predetermined measurement scales.

Table 1. Score Interpretation Criteria.

\begin{tabular}{cc}
\hline Percentage & Category \\
\hline $20 \% \leq$ Nilai $<36 \%$ & Very low \\
$36 \% \leq$ Nilai $<52 \%$ & Low \\
$52 \% \leq$ Nilai $<68 \%$ & Moderate \\
$68 \% \leq$ Nilai $<84 \%$ & Good \\
$84 \% \leq$ Nilai $<100 \%$ & Very good \\
\hline
\end{tabular}

Source: Data processed, 2020

In addition to descriptive analysis for describe how much respondents rated of the variables, the causal study approach was another research objective of this study. Structural equation modeling (SEM) analysis is used to meet the research objectives in analyzing the relationship and level of influence between variables. The structural equation model used is partial least square (PLS-SEM). The PLSSEM analysis method has two components of the evaluation model. The first component is the evaluation of the measurement model or known as the outer model to assess the validity and reliability of the model. The second component is the evaluation of the structural model, usually referred to as the inner model, which aims to predict the relationship between latent variables (Hair et al., 2011). In order to test how well the measurement theory between the variables and the measured factors is in accordance with the facts captured by the data, the measurement model in SEM uses confirmatory factor analysis (CFA) (Hair et al., 2019). 
PLS-SEM analysis in this study was carried out in two levels, that is second order confirmatory factor analysis (SOCFA). The second level of testing in PLS-SEM is used when a construct can conceptually be formed by multidimensional measures that can be measured through its indicators.

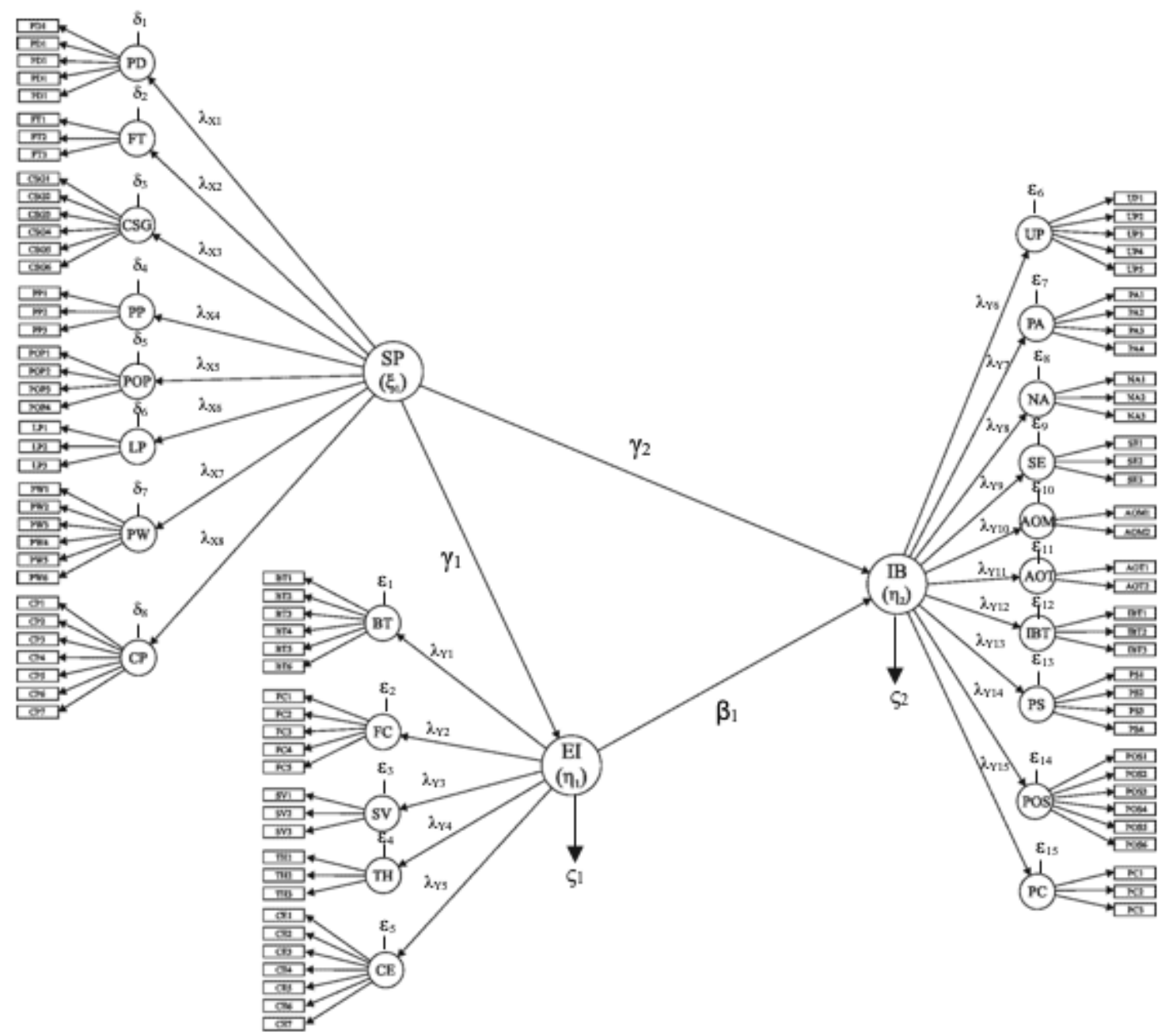

Source: Data processed, 2020

Figure 1. Measurement and Structural Models (SOCFA)

Measurement and structural models that describe the relationship between latent variables and their manifest variables can be explained in the form of the following equation:

Table 2. Measurement Model Equations.

\begin{tabular}{ccc}
\hline $\begin{array}{c}\text { Exogenous latent variable } \\
\text { Sales promotion }(\text { reflective) }\end{array}$ & $\begin{array}{c}1^{\text {st }} \text { Endogenous latent variable } \\
\text { Event image }(\text { reflective) }\end{array}$ & $\begin{array}{c}2^{\text {nd }} \text { Endogenous latent variable } \\
\text { Impulse buying (reflective) }\end{array}$ \\
\hline$x_{1}=\lambda_{x 1} \xi_{1}+\delta_{1}$ & $y_{1}=\lambda_{y 1} \eta_{1}+\varepsilon_{1}$ & $y_{6}=\lambda_{y 6} \eta_{2}+\varepsilon_{6}$ \\
$x_{2}=\lambda_{x 2} \xi_{1}+\delta_{2}$ & $y_{2}=\lambda_{y 2} \eta_{1}+\varepsilon_{2}$ & $y_{7}=\lambda_{y 7} \eta_{2}+\varepsilon_{7}$ \\
$x_{3}=\lambda_{x 3} \xi_{1}+\delta_{3}$ & $y_{3}=\lambda_{y 3} \eta_{1}+\varepsilon_{3}$ & $y_{8}=\lambda_{y 8} \eta_{2}+\varepsilon_{8}$ \\
$x_{4}=\lambda_{x 4} \xi_{1}+\delta_{4}$ & $y_{4}=\lambda_{y 4} \eta_{1}+\varepsilon_{4}$ & $y_{9}=\lambda_{y 9} \eta_{2}+\varepsilon_{9}$ \\
$x_{5}=\lambda_{x 5} \xi_{1}+\delta_{5}$ & $y_{5}=\lambda_{y 5} \eta_{1}+\varepsilon_{5}$ & $y_{10}=\lambda_{y 10} \eta_{2}+\varepsilon_{10}$ \\
$x_{6}=\lambda_{x 6} \xi_{1}+\delta_{6}$ & & $y_{11}=\lambda_{y 11} \eta_{2}+\varepsilon_{11}$ \\
$x_{7}=\lambda_{x 7} \xi_{1}+\delta_{7}$ & & $y_{12}=\lambda_{y 12} \eta_{2}+\varepsilon_{12}$ \\
$x_{8}=\lambda_{x 8} \xi_{1}+\delta_{8}$ & & $y_{13}=\lambda_{y 13} \eta_{2}+\varepsilon_{13}$ \\
& & $y_{14}=\lambda_{y 14} \eta_{2}+\varepsilon_{14}$ \\
& & $y_{15}=\lambda_{y 15} \eta_{2}+\varepsilon_{15}$
\end{tabular}


Meanwhile, to describe the relationship between the latent variable sales promotion, event image and impulse buying, mathematically the structural equation can be written as follows:

$$
\begin{aligned}
& \eta_{1}=\gamma_{1} \xi_{1}+\varsigma_{1} \\
& \eta_{2}=\gamma_{2} \xi_{1}+\beta_{1} \eta_{1}+\varsigma_{2}
\end{aligned}
$$

Evaluation of the measurement model (outer model) is carried out by analyzing the validity and reliability of the construct. The construct validity test consists of convergent validity and discriminant validity tests. Reliability test in PLS-SEM, the measurement model tested can be explained from the coefficient value of Cronbach's alpha and the value of composite reliability. The evaluation of the PLS-SEM (inner model) structural model is carried out to test the strength of the constructs, to analyze the influence between latent variables so that it can be seen whether the hypothesis can be accepted or rejected.

\section{RESULT AND DISCUSSION}

\section{A. Descriptive analysis}

The summary of the descriptive analysis results shows that the respondents' responses to sales promotions are in the good category with an average score of 4.18 or $83.6 \%$, the event image is in the good category with an average score of 4.10 or $81.9 \%$, and impulse buying also is in the good category with an average score of 3.57 or $71.4 \%$.

\section{B. Model analysis PLS-SEM}

The results of the measurement model test (outer model) show that all indicator items have a positive correlation value above 0.20 which indicates that the model has met the convergent validity requirements (Guildford, 1956 in Indrawati, 2015). Besides that, the results of the measurement model test also show that there are indicator items that have a relatively minimum loading factor value, namely the price discount item indicator PD3 $=0.602$, PD4 $=0.683$; free trial indicator on item FT1 $=0.676$; POP indicator display on POP4 items $=0.598$; and the urge to purchase indicator on the UP2 item $=0.536$. While other indicator items have a loading factor value greater than 0.7. This means that the indicator items PD3, PD4, FT1, POP4 and UP2 are still acceptable for use as measuring tools because they still have sufficient convergent validity with a value of at least 0.5 (Hair et al., 2010; in Indrawati 2015) along with other indicator items in each latent variable that have good convergent validity > 0.7 (Chin and Dibbern, 2010; Henseler et al., 2009; Ghozali, 2008; Urbach and Ahlemann, 2010; Vinzi, Trincherra, and Amanto, 2010; in Indrawati, 2015).

Likewise, the discriminant validity test illustrates that the research model has good validity, where the measuring instruments used in the predicted variables construct are not highly correlated. From the Fornell lacker criterion test results, it was found that the square root of AVE value on the sales promotion variable was 0.737 , higher than the correlation between sales promotion with event image (0.649) and with impulse buying (0.359). The square root value of AVE in the event image variable was 0.904 higher than the correlation between event image and sales promotion (0.737) and impulse buying (0.274). Then the square root of AVE value in the impulse buying variable was 0.813 which was higher than the correlation between impulse buying and sales promotion (0.359) and event image (0.274). Thus, all constructs have a square root of AVE value that is greater than the correlation value of this construct with other constructs, so that the measuring instrument in the model meets the requirements for discriminant validity (Indrawati, 2015).

The measurement model shows the results that each latent variable has an average composite reliability (CR) of 0.9 and is confirmed by an average Cronbach's alpha (CA) value of 0.9 as well. Thus, the research instrument used has high reliability, well above 0.7 (Hair et al., 2010; Kaplan and Saccuzzo, 1993; Nunnally and Bernstein, 1994; Pedhazur and Pedhazur, 1991; in Indrawati, 2015) and good above 0.8 (Sekaran and Bougie, 2016). All indicators have accuracy, consistency and exactness in measuring each construct.

Model testing is continued with the structural model (inner model) to analyze the strength of the construct, ensure predictive ability, measure the level of variation in variable changes, measure the value of the resulting observations, validate the overall model performance, and finally evaluate the effect and significance of the relationship between variables. The results obtained are (1) There is no collinearity between constructs, both sales promotion to the event image (VIF value $=1.0$ ) and to impulse buying (VIF value $=$ 1.72), as well as the event image towards impulse buying (value VIF $=1,72$ ). The resulting VIF value is less than 5 , which indicates the absence of collinearity between constructs (Sarstedt et al., 2017). And higher than 0.20 (Hair et al., 2016), thus the research model has good predictive ability because there is no collinearity problem that can bias the regression results. (2) The coefficient of determination ( $\mathrm{R}^{2}$ value) informs the variation of changes in the construct, where there is a direct effect of sales promotion on the event image of 0.421 and sales promotion through the event image affect impulse buying of 0.132 . The magnitude of the substantive influence of the sales promotion construct on the event image construct is large with a value of $\mathrm{f}^{2}=0.727$, while impulse buying is relatively small with a value of $\mathrm{f}^{2}=0.065$ (Cohen, 1988; in Sarstedt et al., 2017). Meanwhile, the event image construct for impulse 
buying shows no substantive effect because the value of $\mathrm{f}^{2}=0,003$ (Sarstedt et al., 2017). (3) The predictive relevance test through the total coefficient of determination $\left(\mathrm{Q}^{2}\right)$ on the path model shows the observed values have been reconstructed well, thus the research model has predictive relevance because the value of sales promotion in influencing event image $\left(Q^{2}=0,332\right)$ and impulse buying $\left(Q^{2}\right.$ $=0,084)$ are both equally has a value of $\mathrm{Q}^{2}>0$ (Sarstedt et al., 2017). The predictive relevance effect size when the sales promotion construct is removed from the model shows a value of $\mathrm{q}^{2}=0.039$ which interprets that the effect is small (Hair et al., 2016). (4) Measurement of the goodness of fit $(\mathrm{GoF})$ index in validating the performance of the structural model as a whole is obtained a relatively large value, that is 0.432 . The greater the GoF index, the more appropriate the model is in explaining empirical data, so that the overall research model formed is fit (Tenenhaus, 2008).

Table 3. Result test of GoF (Goodness of fit).

\begin{tabular}{lccc}
\hline \multicolumn{1}{c}{ Construct } & AVE & R square & GoF $=\left(\sqrt{\overline{A V E} \times \overline{R^{2}}}\right)$ \\
\hline Sales Promotion & 0,544 & - & \\
Event Image & 0,817 & 0,421 & \\
Impulse Buying & 0,661 & 0,132 & 0,432 \\
\hline Average value & 0,674 & 0,276 & \\
\hline
\end{tabular}

Source: Data processed, 2020

\section{Path analysis}

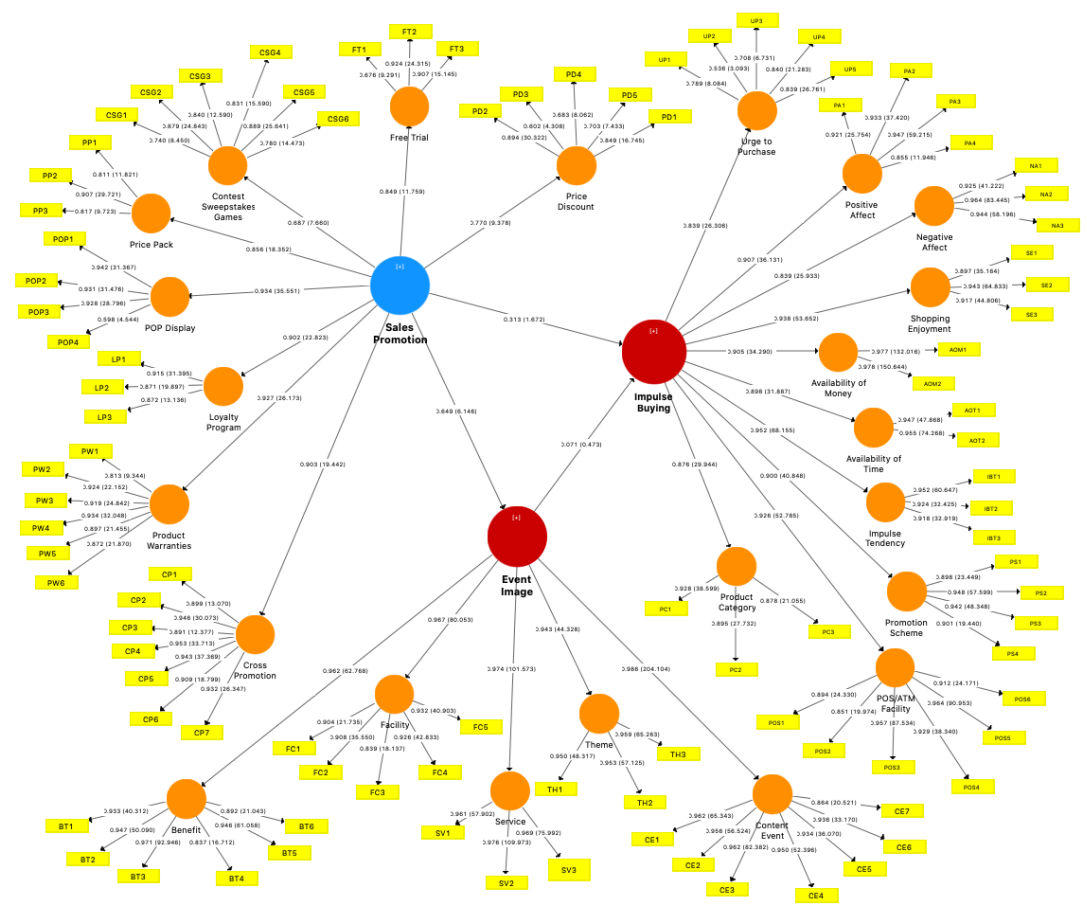

Source: Data processed, 2020

Figure 2. Path Diagram of Full Structural Model (PLS-Bootstrapping)

Based on the path diagram model according to Figure 2, data processing is carried out using the bootstrapping procedure in the software of SmartPLS 3.0, the results of the test recapitulation are obtained based on the path coefficient value and the t-statistic value as follows:

Table 4. Statistic test result

\begin{tabular}{lccc}
\hline \multicolumn{1}{c}{ Constructs relation } & Path Coefficient & T-Statistic & P-Value \\
\hline Sales Promotion > Impulse Buying & 0,313 & 1,672 & 0,048 \\
Event Image > Impulse Buying & 0,071 & 0,473 & 0,318 \\
Sales Promotion > Event Image & 0,649 & 6,146 & 0,000 \\
\hline
\end{tabular}

Source: Data processed, 2020

This publication is licensed under Creative Commons Attribution CC BY. 
The results of statistical testing on the first hypothesis show that the relationship between sales promotion and impulse buying results in a path coefficient value of 0.313 which is positive, this indicates that the relation character between the variables is positive. The calculation of t-value 1,672 > t-table 1,64 for hypothesis testing with an error rate of $5 \%(\alpha=0.05$ for one tailed) and p-value $0,048<$ 0.05 are indicates a significant effect (Abdillah and Hartono, 2015). These results can be interpreted that sales promotion has a positive and significant effect on consumer impulse buying. Its mean that if the sales promotion program was executed by Honda Motor West Java is getting better or improved, it will increase the impulse buying behavior of its consumers. Therefore, the hypothesis $\mathrm{H} 1$ is accepted.

Statistical testing on the second hypothesis about the relationship of the event image variable to impulse buying results in a path coefficient value of 0.071 which is positive. The calculation of t-value $0.473<$ t-table 1.64 and p-value $0.318>0.05$ are indicates no significant effect. These results can be interpreted that event image has no positive and significant effect on consumer impulse buying. This means that the event image generated from the event marketing activities were performed by Honda Motor West Java does not affect the impulse buying behavior of its consumers. Therefore, the $\mathrm{H} 2$ hypothesis is rejected. This result is not in line with the results of previous research, this can be explained because the event image is formed and composed in the mechanism of human memory and knowledge, with its dynamic nature in the human mind because it is influenced by various factors. The factors that caused this difference in results can be identified from the object of previous research that focused on type of FMCG's product (fast moving consumer good), while the object of this study focused on the type of non-FMCG's product, specifically motorcycle is classified as durable goods. Another factor is the characteristics and psychological conditions of respondents as consumers when responding to each stimulation, which greatly affects the response of consumers when giving responses and assessments in each study. Marketing stimuli received by consumers generally will affect the two sides of the consumer's response which are interconnected. First, stimulation will bring forth to responses based on the characteristics of the consumers themselves who have cultural backgrounds, social life and identification as a person. Second, stimulation will generate responses that are based on the psychological condition of consumers including motivation, perception, learning and memory resulting from previous consumer experiences (Kotler and Keller, 2016).

The third hypothesis is about the relationship between the sales promotion variable and the event image, the results of statistical testing produce a path coefficient value of 0.649 which is positive. The calculation of t-value $6.146>\mathrm{t}$-table 1.64 and p-value 0.000 $<0.05$ are indicates a significant effect. These results can be interpreted that sales promotion has a positive and significant effect on the event image. That is, if the sales promotion program was executed by Honda Motor West Java is getting better or improved, it will increase the event image resulting from the event marketing activities that were performed. Therefore, the hypothesis H3 is accepted.

\section{Analysis of intervening effect}

In analyzing the strength of the relationship between predicted variables as a mediator to other variables, the test in this study was carried out by measuring the indirect effect between the sales promotion variable on impulse buying through event image as the mediating variable. Changes in sales promotion variables lead to changes in the event image variable and ultimately lead to changes in the impulse buying variable. To confirm the results of the analysis of the effect of mediation, the author adopts a simple plot on the Baron and Kenny's test model which recommends testing the significance of the indirect pathway using the Sobel Z-test formula approach (Zhao et al., 2010). Data processing was performed using the online Sobel Z-test calculator approach.

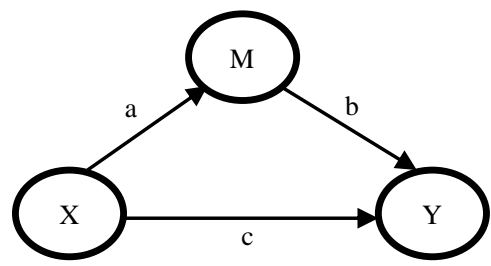

Source: Zhao et al., 2010

Figure 3. Baron and Kenny's test model

Sobel Z-test formula:

$z=\frac{a x b}{\sqrt{b^{2} s_{a}^{2}+a^{2} s_{b}^{2}}}$

were $\mathrm{Z}=$ indirect effect value; $S a=$ standard error a; $S b=$ standard error b 
Table 5. Result test of specific indirect effect

\begin{tabular}{cccc}
\hline Constructs relation & Path Coefficient & T-Statistic & P-Value \\
\hline Sales Promotion $>$ Event Image > Impulse Buying & 0,046 & 0,455 & 0,325 \\
\hline
\end{tabular}

Source: Data processed, 2020

The results of the indirect effect test show that the path coefficient value of 0.046 is positive with the calculation of a t-value of 0.455 $<\mathrm{t}$-table 1.64 and p-value of $0.325>0.05$ are indicates that there is no significant indirect effect. In order to ensure the results of this test and at the same time ensure the answer to the fourth hypothesis regarding the relationship of the sales promotion variable to impulse buying through the event image as a mediating variable, an alternative method of Sobel Z-test was calculated using the path coefficient value parameter and the standard deviation value.

Table 6. Parameter values of Sobel test

\begin{tabular}{ccc}
\hline Constructs relation & Path Coefficient & Standard Deviation (s) \\
\hline Sales Promotion > Event Image (a) & 0,649 & 0,106 \\
Event Image $>$ Impulse Buying (b) & 0,071 & 0,150 \\
\hline
\end{tabular}

Source: Data processed, 2020

Based on the parameter values, the calculation result of Sobel test calculator obtained as follows:

Table 7. Mediation test of the Sobel test method

\begin{tabular}{ccc}
\hline Constructs relation & T-statistic & P-value (one tailed) \\
\hline Sales Promotion $>$ Event Image $>$ Impulse buying & 0,472 & 0,318 \\
\hline
\end{tabular}

Source: Data processed, 2020

The results of the mediation effect test showed that the t-value of $0.472<\mathrm{t}$-table 1.64 and p-value of $0.318>0.05$ are indicates that there was no significant indirect effect. This result can be confirmed that the specific indirect effect test results are same as the Sobel test method, that the event image is not able to mediate the effect of sales promotion on impulse buying. Its means that the achievement of event image for event marketing activities were performed by Honda Motor West Java is not able to increase or decrease the influence of sales promotions was executed in an effort to increase consumer impulse buying behavior. It can be concluded that the hypothesis $\mathrm{H} 4$ is rejected.

\section{CONCLUSION}

Sample's responses about impulse buying are in the good category with an average score of 3.57 or $71.4 \%$. The results of direct effect analysis of sales promotion and event image on impulse buying indicate an effect of 13,2\%, although the magnitude of the substantive influence of sales promotion is relatively small (0.065) and there is no substantive effect of event image (0.003). Based on the results of these two analyzes, it can be concluded that there is a potential for impulse buying on Honda motorcycle products in West Java which can be explained by the influenced of sales promotion program when event marketing activities are carried out, while the resulting event image does not contribute directly to impulse buying.

Hypothesis test regarding the effect of sales promotion on impulse buying shows that there is a positive and significant influence, likewise sales promotion shows a positive and significant effect on event image. As for, event image has no positive and significant effect on impulse buying.

The implication of the conclusion points above can be used as a rationale for the promotion department and the sales department at PT. DAM as the main dealer of Honda Motor in West Java and PT. AHM as the agent of Honda Motor brand in Indonesia to align the objectives set in various lines of event marketing, where event activities can focus specifically aimed at generating hard sales through the option approach of sales promotion incentive tools which can influence consumer impulse buying behavior. 


\section{APPENDIX 1}

\begin{tabular}{|c|c|c|c|c|c|c|}
\hline \multicolumn{2}{|c|}{ Table A1. } & \multicolumn{5}{|c|}{ Descriptive analysis about sales promotion } \\
\hline No. & Indicators & Code & Total score & \% Score & Average & Ideal score \\
\hline 1 & Price Discount & PD & 1263 & $80.2 \%$ & 4.01 & 1575 \\
\hline 2 & Free Trial & FT & 808 & $85.5 \%$ & 4.28 & 945 \\
\hline 3 & $\begin{array}{l}\text { Prize (contests, sweepstakes, } \\
\text { games) }\end{array}$ & CSG & 1483 & $78.5 \%$ & 3.92 & 1890 \\
\hline 4 & Price Pack & PP & 775 & $82.0 \%$ & 4.10 & 945 \\
\hline 5 & POP Display & POP & 1073 & $85.2 \%$ & 4.26 & 1260 \\
\hline 6 & Loyalty Program & LP & 792 & $83.8 \%$ & 4.19 & 945 \\
\hline 7 & Product Warranties & PW & 1627 & $86.1 \%$ & 4.30 & 1890 \\
\hline 8 & Cross Promotion & $\mathrm{CP}$ & 1924 & $87.3 \%$ & 4.36 & 2205 \\
\hline \multicolumn{2}{|c|}{$\begin{array}{l}\text { Score SP } \\
\text { Percentage }\end{array}$} & \multicolumn{2}{|c|}{9745} & & 4.18 & 11655 \\
\hline \multicolumn{2}{|c|}{ Criteria } & Good & & & & \\
\hline
\end{tabular}

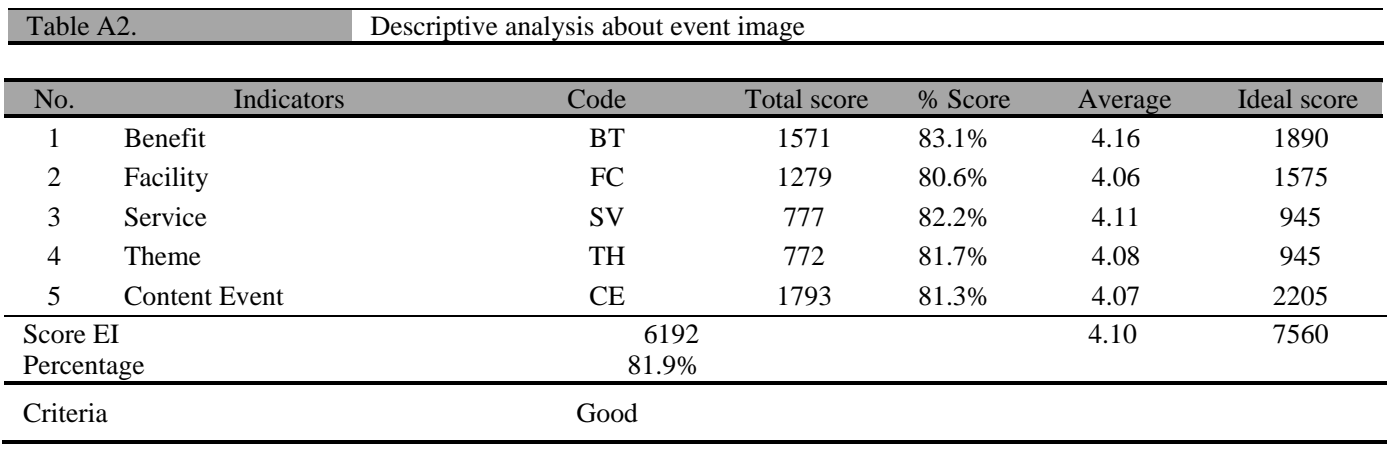

\begin{tabular}{|c|c|c|c|c|c|c|}
\hline \multicolumn{2}{|c|}{ Table A3. } & \multicolumn{5}{|c|}{ Descriptive analysis about impulse buying } \\
\hline No. & Indicators & Code & Total score & $\%$ Score & Average & Ideal score \\
\hline 1 & Urge to Purchase & UP & 1163 & $73.8 \%$ & 3.69 & 1575 \\
\hline 2 & Positive Affect & $\mathrm{PA}$ & 910 & $72.2 \%$ & 3.61 & 1260 \\
\hline 3 & Negative Affect & NA & 665 & $70.4 \%$ & 3.52 & 945 \\
\hline 4 & Shopping Enjoyment & SE & 659 & $69.7 \%$ & 3.49 & 945 \\
\hline 5 & Availability of Money & $\mathrm{AOM}$ & 449 & $71.3 \%$ & 3.56 & 630 \\
\hline 6 & Availability of Time & AOT & 460 & $73.0 \%$ & 3.65 & 630 \\
\hline 7 & Impulse Tendency & IBT & 660 & $69.8 \%$ & 3.49 & 945 \\
\hline 8 & Promotion Scheme & PS & 946 & $75.1 \%$ & 3.75 & 1260 \\
\hline 9 & POS/ATM Facility & POS & 1309 & $69.3 \%$ & 3.46 & 1890 \\
\hline 10 & Product Category & $\mathrm{PC}$ & 653 & $69.1 \%$ & 3.46 & 945 \\
\hline $\begin{array}{l}\text { Score } \\
\text { Perce }\end{array}$ & & $\begin{array}{r}78 \\
71 . \\
\end{array}$ & & & 3.57 & 11025 \\
\hline Criter & & Good & & & & \\
\hline
\end{tabular}


APPENDIX 2

\begin{tabular}{|c|c|c|c|c|c|}
\hline Table B1. & Exploratory Factor Analysis of Sales Promotion (N=63) & & & & \\
\hline Code & Latent Variables and Item Indicator & $\begin{array}{l}\text { Coefficient } \\
\text { Correlation }\end{array}$ & $\begin{array}{l}\text { Loading } \\
\text { Factor }\end{array}$ & $\begin{array}{l}\text { Average Variance } \\
\text { Extracted }\end{array}$ & $\begin{array}{l}\text { Composite } \\
\text { Reliability }\end{array}$ \\
\hline PD & Price Discount & & & 0.569 & 0.866 \\
\hline PD1 & Price discount was the reason I bought a Honda motorcycle. & 0,784 & 0.849 & & \\
\hline PD2 & I feel lucky to get a price discount when buying a Honda motorcycle. & 0,768 & 0.894 & & \\
\hline PD3 & I would buy a motorcycle from another brand if it was discounted. & 0,419 & 0.602 & & \\
\hline PD4 & I favoured other brands, but I chased to buy a Honda motorcycle because it offered a price discount. & 0,454 & 0.683 & & \\
\hline PD5 & The price discount made me buy a Honda motorcycle earlier than planned. & 0,523 & 0.703 & & \\
\hline FT & Free Trial & & & 0.711 & 0.879 \\
\hline FT1 & Tried a Honda motorcycle made me buy it. & 0,611 & 0.676 & & \\
\hline FT2 & I became aware of Honda motorcycles because I was offered to try them out. & 0,776 & 0.924 & & \\
\hline FT3 & Tried a Honda motorcycle made me know about the advantages about the new product offered. & 0,697 & 0.907 & & \\
\hline CSG & Prize: Contest, Sweepstakes, Games & & & 0.686 & 0.929 \\
\hline CSG1 & Contest, sweepstakes, games that I am interested at Honda event are challenging things. & 0,529 & 0.740 & & \\
\hline CSG2 & The prizes at the event made me buy a Honda motorcycle. & 0,633 & 0.879 & & \\
\hline CSG3 & A great opportunity to win a sweepstakes prize at the event made me interested in buying a Honda motorcycle. & 0,638 & 0.840 & & \\
\hline CSG4 & The contest rules that were easy to follow during the event attracted me to buying a Honda motorcycle. & 0,624 & 0.831 & & \\
\hline CSG5 & The procedures for the games that were easy to follow in the event attracted me to buy a Honda motorcycle. & 0,634 & 0.889 & & \\
\hline CSG6 & Prize promotions conducted by Honda with utilize social media attracted me to buy a Honda motorcycle. & 0,720 & 0.780 & & \\
\hline PP & Price Pack & & & 0.716 & 0.883 \\
\hline PP1 & The product package with free service attracted me to buy a Honda motorcycle. & 0,725 & 0.811 & & \\
\hline PP2 & The special package offer as a Honda user made me interested to re-buy a Honda motorcycle. & 0,802 & 0.907 & & \\
\hline PP3 & Offering different product packages from other brands made me interested to buy a Honda motorcycle. & 0,689 & 0.817 & & \\
\hline POP & POP Display & & & 0.743 & 0.918 \\
\hline \multirow[t]{2}{*}{ POP1 } & I'm interested to buy, because the Honda motorcycle display was easily to recognized by the brand. & 0,846 & 0.942 & & \\
\hline & & & & & continuec \\
\hline
\end{tabular}

This publication is licensed under Creative Commons Attribution CC BY. 


\begin{tabular}{|c|c|c|c|c|c|}
\hline Table B1. & (Continued) & & & & \\
\hline Code & Latent Variables and Item Indicator & $\begin{array}{l}\text { Coefficient } \\
\text { Correlation }\end{array}$ & $\begin{array}{l}\text { Loading } \\
\text { Factor }\end{array}$ & $\begin{array}{l}\text { Average Variance } \\
\text { Extracted }\end{array}$ & $\begin{array}{l}\text { Composite } \\
\text { Reliability }\end{array}$ \\
\hline POP2 & I'm interested to buy, because the Honda motorcycle display was styled attractively. & 0,822 & 0.931 & & \\
\hline POP3 & $\begin{array}{l}\text { I'm interested to buy, because the Honda motorcycle display includes pricing information easily to } \\
\text { understand. }\end{array}$ & 0,846 & 0.928 & & \\
\hline POP4 & $\begin{array}{l}\text { The placement of Honda motorcycle displays are close to the transaction facility, made easier for me to } \\
\text { decide to buy it. }\end{array}$ & 0,602 & 0.598 & & \\
\hline $\mathbf{L P}$ & Loyalty Program & & & 0.785 & 0.916 \\
\hline LP1 & I have benefited from the Always Honda program. & 0,849 & 0.942 & & \\
\hline LP2 & I know the function of the Always Honda member card that is given to Honda motorcycle buyers. & 0,727 & 0.871 & & \\
\hline LP3 & The Always Honda program attracted me to make repeat purchases in the future. & 0,756 & 0.872 & & \\
\hline PW & Product Warranties & & & 0.799 & 0.960 \\
\hline PW1 & The engine warranty offered by Honda motorcycle for five years made me interested to make a purchase. & 0,712 & 0.813 & & \\
\hline PW2 & Lost insurance coverage within a certain period makes me comforted to buy a Honda motorcycle. & 0,756 & 0.924 & & \\
\hline PW3 & Guaranteed spare parts replacement within a certain period makes me interested to buy a Honda motorcycle. & 0,809 & 0.919 & & \\
\hline PW4 & $\begin{array}{l}\text { Guaranteed the availability of spare parts repair services through the AHASS repair shop network was my } \\
\text { considerate to buy a Honda motorcycle. }\end{array}$ & 0,785 & 0.934 & & \\
\hline PW5 & Guaranteed facilities for new products in case of problems make me comforted to buy a Honda motorcycle. & 0,884 & 0.897 & & \\
\hline PW6 & The additional warranty period offered by Honda made me interested to make a purchase. & 0,801 & 0.872 & & \\
\hline $\mathbf{C P}$ & Cross Promotion & & & 0.856 & 0.976 \\
\hline $\mathrm{CP} 1$ & I have been came to a big event sponsored by Honda. & 0,731 & 0.899 & & \\
\hline $\mathrm{CP} 2$ & Knowing the sponsor of the big event was Honda, I became believed to the Honda brand. & 0,763 & 0.946 & & \\
\hline $\mathrm{CP} 3$ & A lot of Honda logos at the big event helped me find out about the existence of Honda motorcycle. & 0,804 & 0.891 & & \\
\hline $\mathrm{CP} 4$ & From this big event, I learned the advantages of Honda products. & 0,816 & 0.953 & & \\
\hline CP5 & I was able to see the unit product of Honda motorcycle at the big event in person. & 0,801 & 0.943 & & \\
\hline CP6 & In this big event, I had a wonderful experience with Honda motorcycle. & 0,754 & 0.909 & & \\
\hline $\mathrm{CP} 7$ & In this big event, Honda provided attractive product offers. & 0,835 & 0.932 & & \\
\hline
\end{tabular}




\begin{tabular}{|c|c|c|c|c|c|}
\hline Table B2. & Exploratory Factor Analysis of Event Image $(\mathrm{N}=63)$ & & & & \\
\hline Code & Latent Variables and Item Indicator & $\begin{array}{l}\text { Coefficient } \\
\text { Correlation }\end{array}$ & $\begin{array}{l}\text { Loading } \\
\text { Factor }\end{array}$ & $\begin{array}{l}\text { Average Variance } \\
\text { Extracted }\end{array}$ & $\begin{array}{l}\text { Composite } \\
\text { Reliability }\end{array}$ \\
\hline BT & Benefit & & & 0.850 & 0.971 \\
\hline BT1 & The event that Honda held satisfied my curiosity about Honda motorcycle products. & 0,902 & 0.933 & & \\
\hline $\mathrm{BT} 2$ & The event that Honda held expanded my insight into safety riding through to try a Honda motorcycle directly. & 0,917 & 0.947 & & \\
\hline ВT3 & I learned about new technology from an event that Honda held. & 0,938 & 0.971 & & \\
\hline BT4 & I learned about the latest lifestyle trends from the event that Honda held. & 0,772 & 0.837 & & \\
\hline BT5 & I found new ideas from event that Honda held. & 0,906 & 0.946 & & \\
\hline BT6 & The event that Honda held improved my social relationship by met peoples. & 0,875 & 0.892 & & \\
\hline $\mathbf{F C}$ & Facility & & & 0.815 & 0.956 \\
\hline $\mathrm{FC} 1$ & The event that Honda organized has good safety system. & 0,912 & 0.904 & & \\
\hline FC2 & The event that Honda organized has good cleaning facilities. & 0,890 & 0.908 & & \\
\hline FC3 & The event that Honda organized is equipped with a comfortable air conditioning system. & 0,760 & 0.839 & & \\
\hline FC4 & The event that Honda organized is equipped with convenience special seats for transactions. & 0,884 & 0.926 & & \\
\hline FC5 & The event that Honda organized is equipped with good information service facilities. & 0,906 & 0.932 & & \\
\hline SV & Service & & & 0.938 & 0.978 \\
\hline SV1 & The event that Honda held was carried out by a neat-looking staffs. & 0,933 & 0.961 & & \\
\hline SV2 & The Honda event staffs were provided high-quality service. & 0,941 & 0.976 & & \\
\hline SV3 & All staff in the Honda event are friendly to every visitor. & 0,957 & 0.969 & & \\
\hline TH & Theme & & & 0.910 & 0.968 \\
\hline TH1 & I know about that Honda event from one of media Honda publication. & 0,860 & 0.950 & & \\
\hline $\mathrm{TH} 2$ & I think the name of that Honda event is unique. & 0,899 & 0.953 & & \\
\hline TH3 & The tittle of event that Honda held had accordance with the contents of activities that were realized. & 0,937 & 0.959 & & \\
\hline $\mathbf{C E}$ & Content Event & & & 0.881 & 0.981 \\
\hline CE1 & In the Honda event, the performance show was interesting. & 0,957 & 0.962 & & \\
\hline CE2 & At the Honda event, there was a unique product display exhibition. & 0,938 & 0.956 & & \\
\hline CE3 & In the Honda event, there were a unique interactive activities. & 0,944 & 0.962 & & \\
\hline CE4 & The area sign system in that Honda event can control the flow of visitors effectively. & 0,937 & 0.950 & & \\
\hline
\end{tabular}




\begin{tabular}{|c|c|c|c|c|c|}
\hline Table B2. & (Continued) & & & & \\
\hline Code & Latent Variables and Item Indicator & $\begin{array}{l}\text { Coefficient } \\
\text { Correlation }\end{array}$ & $\begin{array}{c}\text { Loading } \\
\text { Factor }\end{array}$ & $\begin{array}{l}\text { Average Variance } \\
\text { Extracted }\end{array}$ & $\begin{array}{l}\text { Composite } \\
\text { Reliability }\end{array}$ \\
\hline CE5 & There are regular queue arrangements at the Honda event. & 0,910 & 0.934 & & \\
\hline CE6 & The Honda event was hosted by an interactive presenter. & 0,937 & 0.936 & & \\
\hline CE7 & The guest stars at the Honda event were well known artists who were rising in popularity. & 0,848 & 0.864 & & \\
\hline Table B3. & Exploratory Factor Analysis of Impulse Buying $(\mathrm{N}=63)$ & & & & \\
\hline Code & Latent Variables and Item Indicator & $\begin{array}{l}\text { Coefficient } \\
\text { Correlation }\end{array}$ & $\begin{array}{c}\text { Loading } \\
\text { Factor }\end{array}$ & $\begin{array}{l}\text { Average Variance } \\
\text { Extracted }\end{array}$ & $\begin{array}{l}\text { Composite } \\
\text { Reliability }\end{array}$ \\
\hline UP & Urge to Purchase & & & 0.564 & 0.863 \\
\hline UP1 & At that time, I bought a Honda motorcycle spontaneously. & 0,623 & 0.789 & & \\
\hline UP2 & At that time, I did not actually plan to buy a Honda motorcycle. & 0,274 & 0.536 & & \\
\hline UP3 & "Buy now, think later" described my thoughts when buying a Honda motorcycle at that time. & 0,574 & 0.708 & & \\
\hline UP4 & At first, I was just looking at Honda motorcycle products that were exhibiting at the mall. & 0,749 & 0.840 & & \\
\hline UP5 & When I looked at motorcycle product exhibition at the mall, I felt the urge to buy it right away. & 0,784 & 0.839 & & \\
\hline $\mathbf{P A}$ & Positive Affect & & & 0.837 & 0.953 \\
\hline PA1 & At that time, I was feeling excited, so I decided to buy a Honda motorcycle right away. & 0,844 & 0.921 & & \\
\hline PA2 & At that time, I was enthused that I decided to buy a Honda motorcycle right away. & 0,811 & 0.933 & & \\
\hline PA3 & I was proud to buy a Honda motorcycle right away. & 0,810 & 0.947 & & \\
\hline PA4 & I decided to buy a Honda motorcycle right away, because I felt inspired by it. & 0,837 & 0.855 & & \\
\hline NA & Negative Affect & & & 0.892 & 0.961 \\
\hline NA1 & At that time, I was feeling depressed, so I decided spontaneously to buy a Honda motorcycle right away. & 0,810 & 0.925 & & \\
\hline NA2 & At that time, I was feeling disappointed, so I decided spontaneously to buy a Honda motorcycle right away. & 0,757 & 0.964 & & \\
\hline NA3 & At that time, I was feeling sensitive offended, I decided spontaneously to buy a Honda motorcycle right away. & 0,786 & 0.944 & & \\
\hline SE & Shopping Enjoyment & & & 0.845 & 0.942 \\
\hline SE1 & $\begin{array}{l}\text { When I was at the mall, I bought a Honda motorcycle spontaneously, because for me shopping was just my } \\
\text { spare time. }\end{array}$ & 0,811 & 0.897 & & \\
\hline
\end{tabular}




\begin{tabular}{|c|c|c|c|c|c|}
\hline Table B3. & (Continued) & & & & \\
\hline Code & Latent Variables and Item Indicator & $\begin{array}{l}\text { Coefficient } \\
\text { Correlation }\end{array}$ & $\begin{array}{c}\text { Loading } \\
\text { Factor }\end{array}$ & $\begin{array}{l}\text { Average Variance } \\
\text { Extracted }\end{array}$ & $\begin{array}{l}\text { Composite } \\
\text { Reliability }\end{array}$ \\
\hline SE2 & At the mall, I bought a Honda motorcycle spontaneously, because shopping is one of my favourite activities. & 0,892 & 0.943 & & \\
\hline SE3 & Buying a Honda motorcycle at the mall is a fun experience. & 0,873 & 0.917 & & \\
\hline AOM & Availability of Money & & & 0.956 & 0.977 \\
\hline AOM1 & $\begin{array}{l}\text { I bought a Honda motorcycle spontaneously being used to shopping for more than was necessary when I had } \\
\text { cash. }\end{array}$ & 0,880 & 0.977 & & \\
\hline AOM2 & I bought a Honda motorcycle spontaneously having the cash to pay the required down payment. & 0,885 & 0.978 & & \\
\hline AOT & Availability of Time & & & 0.905 & 0.950 \\
\hline AOT1 & I bought a Honda motorcycle spontaneously, because it was free time. & 0,815 & 0.947 & & \\
\hline АOT2 & $\begin{array}{l}\text { At that time, I just spent my time for looking the Honda motorcycle on displayed, until I finally decided to buy } \\
\text { one. }\end{array}$ & 0,883 & 0.955 & & \\
\hline IBT & Impulse Tendency & & & 0.867 & 0.951 \\
\hline IBT1 & I felt strong urge to buy suddenly to buy a Honda motorcycle right away. & 0,897 & 0.952 & & \\
\hline IBT2 & My experience of buying a Honda motorcycle spontaneously was very enjoyable. & 0,879 & 0.924 & & \\
\hline IBT3 & I am a person who made a purchase of Honda motorcycle without any prior planning. & 0,883 & 0.918 & & \\
\hline PS & Promotion Scheme & & & 0.851 & 0.958 \\
\hline PS1 & $\begin{array}{l}\text { The product promotion with the words "limited edition" aroused my passion to buy a Honda motorcycle right } \\
\text { away. }\end{array}$ & 0,837 & 0.898 & & \\
\hline PS2 & The discount prompted me to buy a Honda motorcycle right away. & 0,844 & 0.948 & & \\
\hline PS3 & Prize vouchers motivated me to buy a Honda motorcycle right away. & 0,839 & 0.942 & & \\
\hline PS4 & At that time, I bought a Honda motorcycle, because I remembered the ad. & 0,808 & 0.901 & & \\
\hline POS & POS Terminal / ATM & & & 0.844 & 0.970 \\
\hline POS1 & I bought a Honda motorcycle right away without worrying about payment problems as I have a debit card. & 0,856 & 0.894 & & \\
\hline POS2 & I bought a Honda motorcycle right away without worrying about payment problems as I have a credit card. & 0,725 & 0.851 & & \\
\hline POS3 & I bought a Honda motorcycle without planning, because of the affordable down payment conditions relatively. & 0,908 & 0.957 & & \\
\hline POS4 & $\begin{array}{l}\text { I bought a Honda motorcycle without planning, because of the easy payment facilities offered through the } \\
\text { instalment system. }\end{array}$ & 0,853 & 0.929 & & \\
\hline
\end{tabular}




\begin{tabular}{|c|c|c|c|c|c|}
\hline Table B3. & (Continued) & & & & \\
\hline Code & Latent Variables and Item Indicator & $\begin{array}{l}\text { Coefficient } \\
\text { Correlation }\end{array}$ & $\begin{array}{c}\text { Loading } \\
\text { Factor }\end{array}$ & $\begin{array}{l}\text { Average Variance } \\
\text { Extracted }\end{array}$ & $\begin{array}{l}\text { Composite } \\
\text { Reliability }\end{array}$ \\
\hline POS5 & I bought a Honda motorcycle right away, because of the ease of payment using an ATM debit card. & 0,912 & 0.964 & & \\
\hline POS6 & I bought a Honda motorcycle right away, because of the ease of payment by credit card. & 0,841 & 0.912 & & \\
\hline $\mathbf{P C}$ & Product Category & & & 0.811 & 0.928 \\
\hline PC1 & The launch of a new Honda motorcycle product at the mall tends to make me buy it. & 0,858 & 0.928 & & \\
\hline PC2 & $\begin{array}{l}\text { I bought a Honda motorcycle without planning, because I could spend most of my income on items that were } \\
\text { not household necessities. }\end{array}$ & 0,795 & 0.895 & & \\
\hline PC3 & I bought a Honda motorcycle spontaneously, because it was easy for me to decide to buy automotive product. & 0,704 & 0.878 & & \\
\hline
\end{tabular}




\section{ACKNOWLEDGMENT}

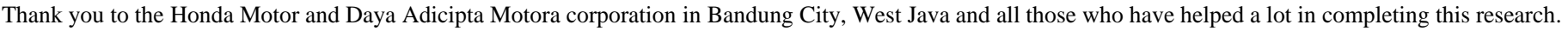

\section{REFERENCES}

[1] Abdillah, W., and Hartono. (2015). Partial Least Square (PLS). Yogyakarta: Andi

[2] Amanah, D., and Pelawi, S. P. (2015). The Effect of Hedonic Sales and Shopping Promotion on Impulse Buying of Matahari Plaza Medan Fair Products. Quanomic, 3(2), 10-18. Retrieved from ResearchGate.

[3] ARF (2019, 4 Januari). Jawa Barat Masih Jadi Penyerap Motor Terbanyak. Portal Industri Otomotif Indonesia News, Manufaktur, \& Gaya Hidup Terkini [online]. Retrieved from: https://www.motoris.id/manufaktur/19886/jawa-barat-masih-jadi-penyerap-motor-baru-terbanyak/ (14 April 2020].

[4] Asosiasi Industri Sepedamotor Indonesia. (2020). Statistic Distribution. [online]. Retrieved from: https://www.aisi.or.id/statistic/ [6 Maret 2020].

[5] Babin, B. J., and Harris, E. G. (2016). Customer Behavior ( $7^{\text {th }}$ student ed.). Boston, USA: Cengage Learning.

[6] Beatty, S. E., and Ferrell, M. E. (1998). Impulse Buying: Modeling Its Precursors. Journal of Retailing, 74(2), 169-191. Retrieved from ScienceDirect.

[7] Clow, K. E., and Baack, D. (2018). Integrated Advertising, Promotion, and Marketing Communications (8 ${ }^{\text {th }}$ ed.). United Kingdom: Pearson.

[8] Cooper, D. R., and Schindler, P. S. (2014). Business Research Methods (12 ${ }^{\text {th }}$ ed.). New York, America: McGraw-Hill.

[9] Corporate Profile PT. AHM (2020). PT Astra Honda Motor [online]. Retrieved from: https://www.astra-honda.com/corporate [14 April 2020].

[10] Corporate Profile PT. DAM (2020). PT Daya Adicipta Motora [online]. Retrieved from: https://www.daya-motora.com/about [14 April 2020].

[11] Deng, C. Q., Li, M., and Shen, H. (2015). Developing A Measurement Scale for Event Image. Journal of Hospitality \& Tourism Research, 39(2), 245-270. Retrieved from Sage Journals.

[12] Free Sobel Test Calculator for the Significance of Mediation (2020). [online]. Retrieved from: https://www.danielsoper.com/statcalc/calculator.aspx?id=31c [28 September 2020]

[13] Gischa, S. (2020, 20 Januari). Dampak Globalisasi di Berbagai Bidang. Kompas [online], p.2. Retrieved from: https://www.kompas.com [18 Maret 2020].

[14] Hair, J. F., Ringle, C. M., and Sarstedt, M. (2011). PLS-SEM: Indeed a Silver Bullet. Journal of Marketing Theory and Practice, 19(2), 139-152. Retrieved from ResearchGate.

[15] Hair Jr, J., Hult, G. T., Ringle, C., and Sarstedt, M. (2016). A Primer on Partial Least Squares Structural Equation Modeling (PLS-SEM) (2 ${ }^{\text {nd }}$ ed.). Los Angeles, USA: Sage.

[16] Hair, J. F., Black, W. C., Babin, B. J., and Anderson, R. E. (2019). Multivariate Data Analysis (8 ${ }^{\text {th }}$ ed.). Hampshire, United Kingdom: Cengage Learning.

[17] Hallmann, K., Kaplanidou, K., and Breuer, C. (2011). Event Image Perceptions Among Active and Passive Sports Tourists at Marathon Races. International Journal of Sports Marketing and Sponsorship, 12(1), 32-47. Retrieved from Emerald Insight.

[18] Husnain, M., and Akhtar, M. W. (2016). Impact of Branding on Impulse Buying Behavior: Evidence from FMCG'S Sector Pakistan. International Journal of Business Administration, 7(1), 59-68. Retrieved from ResearchGate.

[19] Husnul, H. S., Bambang, I., and Andi, S. R. (2017). The Impact of Product Quality, Promotion and Brand Image on Brand Loyalty and Impulse Buying Consumer Oriflame in Jember. International Journal of Business and Management Invention, 6(12), 1-5. Retrieved from Ijbmi.org.

[20] Indrawati, P. D. (2015). Metode Penelitian Manajemen dan Bisnis Konvergensi Teknologi Komunikasi dan Informasi. Bandung: PT Refika Aditama.

[21] Jobber, D., and Lancaster, G. (2015). Selling \& Sales Management (10 ${ }^{\text {th }}$ ed.). Edinburgh Gate, Harlow, United Kingdom: Pearson.

[22] Kemenperin (2019, 1 Januari). Making Indonesia 4.0 Kunci Industri Nasional Berdaya Saing Global di Era Digital. Kementerian Perindustrian Republik Indonesia [online]. Retrieved from: https://kemenperin.go.id/artikel/20065/ [6 Maret 2020].

[23] Kotler, P., and Armstrong, G. (2018a). Principles of Marketing (17 $7^{\text {th }}$ Ed.). New York, USA: Pearson.

[24] Kotler, P., Armstrong, G., and Opresnik, M.O. (2018b). Principles of Marketing (17 ${ }^{\text {th }}$ ed.). Harlow, United Kingdom: Pearson.

[25] Kotler, P., and Keller, K.L. (2016). Marketing Management (15 ${ }^{\text {th }}$ ed.). Edinburgh Gate, Harlow, England: Pearson.

[26] Kuswaraharja, D. (2020, 21 Januari). Penjualan Motor 2019 Capai 6,48 Juta, Tahun 2020 Tak Beda Jauh. DetikOto [online]. Retrieved from: https://oto.detik.com/motor/d-4866984/penjualan-motor-2019-capai-648-juta-tahun-2020-tak-beda-jauh [18 Maret 2020].

[27] Mamuaya, N. C. (2018). The Effect of Sales Promotion and Store Atmosphere on Hedonic Shopping Motivation and Impulsive Buying Behavior in Hypermart Manado City. Development Research of Management, 13(1), 83-99. Retrieved from ResearchGate.

[28] Metilda, R. M., and Karthika, M. (2015). The Impact Of Sales Promotion On Hedonic Value And Utilitarian Value On Impulse Buying. Paripex Indian Journal Of Research World Wide Journals, 4(10), 34-37. Retrieved from ResearchGate

[29] Montaner, T., and Pina, J. M. (2008). The Effect of Promotion Type and Benefit Congruency on Brand Image. Journal of Applied Business Research, 24(3), 1528. Retrieved from Semantic Scholar.

[30] Pradhan, V. (2018). Study on Impulsive Buying Behavior Among Consumers in Supermarket in Kathmandu Valley. Journal of Business and Social Sciences Research, 1(2), 215-233. Retrieved from ResearchGate.

[31] Rook, D. W. (1987). The Buying Impulse. Journal of Consumer Research, 14(2), 189-199. Retrieved from Oxford Academic.

[32] Sarstedt, M., Ringle, C. M., and Hair Jr, J. (2017). Partial Least Squares Structural Equation Modeling. Handbook of Market Research, 1- 40. Retrieved from Springer Link.

[33] Sekaran, U., and Bougie, R. (2016). Research Methods for Business ( $7^{\text {th }}$ ed.). Chichester, West Sussex, United Kingdom: Wiley.

[34] Shimp, T. A., and Andrews, J. C. (2013). Advertising, Promotion, and Other Aspects of Integrated Marketing Communications (9 ${ }^{\text {th }}$ ed.). South-Western, Mason, USA: Cengage Learning.

[35] Sinha, S. K., and Verma, P. (2018). Impact of Sales Promotion's Benefits on Brand Equity: An Empirical Investigation. Global Business Review, 19(6), 1-18. Retrieved from Sage Journals.

This publication is licensed under Creative Commons Attribution CC BY.

http://dx.doi.org/10.29322/IJSRP.11.01.2021.p10986

WWW.ijsrp.org 
ISSN 2250-3153

[36] Solomon, M. R., Bamossy, G. J., Askegaard, S., and Hogg, M. K. (2016). Consumer behaviour A European Perspective (6 ${ }^{\text {th }}$ ed.). Edinburg Gate, Harlow, United Kingdom: Pearson.

[37] Sugiyono. (2018). Metode Penelitian Kuantitatif, Kualitatif dan R\&D. Bandung: Alfabeta.

[38] Tenenhaus, M. (2008). Component-Based Structural Equation Modelling. Total Quality Management and Business Excellence, 19(7-8), 871-886. Retrieved from ResearchGate.

[39] Weerathunga, A.K., and Pathmini, M.G.S. (2016). Impact of Sales Promotion on Consumer's Impulse Buying Behaviour; Study in Supermarkets in Anuradhapura City. International Research Symposium Rajarata University of Sri Lanka, 1, 321-329. Retrieved from ResearchGate.

[40] Wirtz, J., and Lovelock, C. (2018). Essentials of Service Marketing ( ${ }^{\text {rd }}$ ed.). Edinburgh Gate, Harlow, England: Pearson.

[41] Zhao, X., Lynch, J. G., and Chen, Q. (2010). Reconsidering Baron and Kenny: Myths and Truths About Mediation Analysis. Chicago Journal of Consumer Research Inc., 37(2), 197-206. Retrieved from ResearchGate.

[42] Zimmerman, I. (2012, 18 Juli). What Motivates Impulse Buying? Psychology Today [online]. Retrieved from : https://www.psychologytoday.com/us/blog/sold/201207/what-motivates-impulse-buying [3 April 2020].

\section{AUTHORS}

First Author - Mohamad Ropik, Master Management of Science, Telkom University Bandung, Indonesia.

Second Author - Dr. Maya Ariyanti, Lecturer at The Faculty of Economics and Business, Telkom University Bandung, Indonesia. Correspondence Author - ropcreator@gmail.com, +62 8156228073 